\title{
Enduring passions : The fallacies of "gender-focused" development in Kenya
}

\section{Stella Nyancham-Okemwa}

\section{(2) OpenEdition \\ 1 Journals}

Electronic version

URL: http://journals.openedition.org/apad/255

DOI: 10.4000/apad.255

ISSN: 1950-6929

Publisher

LIT Verlag

\section{Printed version}

Date of publication: 20 December 2000

\section{Electronic reference}

Stella Nyancham-Okemwa, "Enduring passions : The fallacies of "gender-focused" development in Kenya », Bulletin de l'APAD [Online], 20 | 2000, Online since 07 April 2006, connection on 10 December 2020. URL : http://journals.openedition.org/apad/255 ; DOI : https://doi.org/10.4000/apad.255

This text was automatically generated on 10 December 2020.

Bulletin de l'APAD 


\title{
Enduring passions : The fallacies of "gender-focused" development in Kenya
}

\author{
Stella Nyancham-Okemwa
}

1 "Women in development" (WID) was coined as an acronym, phrase, concept, program, platform and research focus during the course of the UN Decade for Women 1975-1985 (Glazer, 1991). The coinage of "gender and development" (GAD) in the 1980's, theoretically expanded its concept from "women's promotion" to the "improvement of a quality of life" for all members of the society, regardless of sex, race or class distinction (Snyder and Tadesse, 1993). Notwithstanding this conceptual expansion, most Kenyans tend to associate its "welfare" approach with the missionary "promotion of women" in the 1930's (Sigot, 1995). This paper is a critique on the WID ad GAD tendency to equate "gender" with "women" and thereby exclude men from "gender-focused" development. It seeks to analyse the impact this has had in generating a repertoire of fallacies that have ultimately contributed to its apparent failure. Its discourse is embedded in a broader development framework which is briefly outlined below.

The metamorphosis and unfolding of the development discourse

2 Development in the 1950s and 1960s, tended to be viewed from the perspective of the North (the core) in search of markets, cheap raw materials and labour in the South (the periphery), so as to sustain their capitalist existence (Schuurman, $1993: 2$; Snyder and Tadesse, 1995 :6). An "import substitution" strategy was adopted to encourage the cumulative expansion of a "modem" urban economy, designed to produce for the international market (Stamp, 1989 ; Schuurman, 1993). Since men were associated with the larger social, political and economic circles, the focus was on their contribution to urban and industrial progress. Women's contribution, viewed from their reproductive capacity as mothers and wives, was ignored because they were regarded as having little or no productive impact within these circles (Snyder and Tadesse, $1995: 8$ ). They were associated with "traditional" subsistence practices in the rural sector, which were 
viewed as obstacles to urban progress (Stamp, $1989: 12$ ). They were either dismissed as a "hindrance to development" or stereotyped as "passive" recipients of "relief aid" (Moser, 1989 ; Snyder and Tadesse, 1995 :9-10).

3 The 1970s was characterised with rising concerns about population growth and the degradation of the environment. A new wave of theorists advocated "sustainable" development whereby the rich and the poor countries had to make some adjustments, so as to counter the potentially catastrophic effect global trade was having on the environment (Schuurman, 1993). The promotion of women was viewed as a feasible strategy to provide families with the minimum requirements for consumption and essential community services (Schuurrnan, 1993 : 124). Socialist theorists advocated a "human resources" approach whereby women were viewed as being pertinent rather than peripheral to national development" (Snyder and Tadesse, 1995: 10). This approach paved the way for the current "gender-focused" development (Snyder and Tadesse, 1995 : II).

4 Towards the latter years of the 1970's, trade in the South suffered from the combined effects of the declining global economy, deteriorating terms of trade and, increased market restrictions (Woestman, 1994). The South had to make some adjustments in their trade and governance practices so as be legible for loans to repay their debts and recover from the crisis (Woestman, $1994: 6)$. The International Monetary, Fund (IMF) and the World Bank imposed "Structural Adjustment Programmes" (SAPs). These SAPs include the democratisation of governments, privatisation, deregulation and, retrenchment of the public sector and liberalisation of markets. The promotion of women was viewed as a viable strategy of alleviating a number of SAPs-related problems and/or indirectly containing those that could not be avoided. Small women's organisations were expected to take over almost overnight from the state, without time, resources or experience (Schuurman, 1993 : 174).

5 The term "gender", since the beginning of its use in the development circles, has been distorted in order to fit into a westernised vision of women 's status and their access to resources. This paper will focus on the two "gender" concepts that are encapsulated in the WID and GAD frameworks. WID can be traced to the 1970's liberal/radical feminists reaction to population programmes that were aimed at controlling women's fertility and alleviating poverty (Stamp, 1990: 15-16; Snyder and Tadesse, $1993: 12$ ). They described women as having a triple role in production (income generation), reproduction (biological and social) and in community management (women's networking systems) (Moser, 1989). Development should capitalise on women's triple role so as to make them efficient managers of poverty and thereby buffer the shocks of SAPs policies (Schuurman, 1993 : 170 ; Stamp, 1990).

6 GAD can be traced from the Marxist/socialist feminists' reaction against capitalism (Stamp, 1990). They advocated an "equality" approach which viewed women as victims of male-skewed capitalist structures which sustained and perpetuated unequal distribution of resources, power imbalances and lack of reciprocity between sexes (Stamp, 1990: 16-19; Moser, 1989). In the mid-1980s, local feminists adopted the "empowerment" approach which cut across class lines and embed notions of gender within these structures (Snyder and Tadesse, 1995: 13-14; Dolphyne, 1991; Nyanchama-Okemwa, 1996). They sought to use women's "triple role" politically so as to stimulate a number of structural changes which were more attuned to their practical needs. 
7 In the late 1980 's, the advocates of the "empowerment" approach popularised the term "gender" as a replacement to "women" (Snyder and Tadesse, 1995 : 14). Its proponents claimed that "men and women play different and yet complementary roles in society and therefore have different needs and strategies (Sigot, 1995 :2). Patriarchal structures have the propensity of aggravating their inherently asymmetrical gendered relationships in the spheres of production and reproduction, inside and outside the household (Sigot, 1995; Stamp, 1990). Il is the suggestion of this paper that the subordination and exploitation of women does not take place between sexes precisely nor is it solely triggered by the se underlying gender asymmetries. My critique of the WID and GAD frameworks that are embedded in the "gender-focused" development will be limited to the following four fallacies :

- women are "victims" of patriarchal structures

- women are "passive recipients" of "gender-focused" development

- women networks are "homogeneous" thus its members are mutually concerned with addressing common issues

- "women's Bureau" epitomises the success of both the WID and GAD interventions Women as victims of Patriarchal structures : the first fallacy

8 The first fallacy is founded upon the assumption that the women for whom "gender-focused" development is targeted, exist in societies that are skewed in favour of men. The Kenyan statutory law excludes women from both control and ownership of resources white protecting their rights of access and use. Conversely, traditional valuations of the land do not allude to absolute ownership perse, but rather to gender differentiated access to, use and control of the land. In this sense, one can only talk of relative or partial ownership that is organised around male and female hierarchies, wherein men are just as vulnerable as women to other men and women. Nowadays, the land rights of impoverished, rural-based illiterate men have been impinged upon by a number of wealthy, elite, urban-based and politically powerful men and women. These local bourgeoisie have the political and monetary clout to hoard, lease, commodity or forcibly appropriate land from their impoverished and non-elite kin.

Currently, land has became one of the most valued and contested resource in combating the negative effects of inflation, food deficit, loss of urban real wages, underemployment, unemployment, collapse of health, education and social infrastructure (Francis, 1995 :201). These factors have the propensity of exacerbating the existing power imbalances between the dominant rich minority and the marginalised poor. In this sense, both men and women today, are more concerned with protecting their gender differentiated rights of access to, use and control rather than pursuing the notion of "who owns the land? ". However, since men in general (and recently, wealthy women elite) are the official title deed holders, impoverished, rural-based illiterate women are at the loosing end of this struggle for land rights.

Research indicates that power relations with respect to the land in most agro-pastoral societies is in the hands of senior men, who collude to limit younger men and women's access to and use of land (Hartman, 1979). Since women in these societies have to defer to the authority of men, WID policies presume that they are structurally denied access to, use and control of the land. Similarly, GAD policies, on the basis of this assumption, are aimed at promoting women's interests at the expense of men who may be similarly disadvantaged. The WID and GAD approaches tend to draw a sharp distinction between class and gender, whereby the latter is viewed in terms of relations of human 
reproduction. However, their conception of these relations differs such that WID emphasises women's childbearing and rearing capacities while GAD stresses on the asymmetric gender and generational relations (Henn, 1988 :27).

11 The WID and GAD policies tend to overlook the fact that cultural ideas about gender can be used by both men and women to advance their respective interests regarding productive resources (Bulow, 1992). Moreover, both men and women manipulate and reinterpret customary as well as externally induced ideas about gender. These gender dynamics tend to be obscured when the status of women is viewed from the "mode of economy" perspective that is encapsulated in patriarchy (Stamp, 1989:75). This patriarchal thinking emerges from a theoretical model of class relations whereby male patriarchs, as heads of households, control their dependants' access to the means of production (Henn, $1988: 28$ ). In the pre-capitalist mode of production, patriarchal control was associated with heavy labour burdens for women, some work for male dependants and little or no work for eiders. Similarly, the capitalist mode of production that favours wage differentials and profit-oriented economic growth, has created male-dominated class distinctions between the "haves" and the "have-nots" (Stichter and Parpart, 1988).

12 The idea of patriarchy that is embedded in the WID and GAD gender conceptions presumes a universal domination of women by men (Stamp, 1989 :75). Similarly ingrained in this patriarchal thinking is a dichotomy between a "public" male sphere of politics and economy and a "private" female sphere of family and community welfare (Stamp, 1989 :116). GAD presumes an existence of a uniform male "public" space or style in which women are excluded (Stamp, 1989 : 115). It also presumes an existence of a uniform female public in whose interest policy is made. These assumptions give rise to the idea that formal political legitimacy can only be gauged in terms of an idiom of public interest or common welfare. WID tends to bracket local women into "private", "domestic", "invisible", "dominated" spheres that fall outside of the aforementioned "public" spheres (Stamp, 1989 ; Stichter and Parpart, 1988).

This "public" and "private" dichotomy is irrelevant in societies wherein ail individuals are equally dependant on a collective that was larger than the nuclear family. In the past, eider men and women, either singly or in age group collectivities, were credited for making decisions on behalf of their dependants, about socially defined activities and responsibilities. These activities, responsibilities and the decisions taken about them constituted the public life of the society as a whole (Stamp, 1989:76). In the contemporary Kenyan society, men and women tend to perceive themselves and be perceived by those with whom they are relating in terms of certain idiosyncratic valuations of maleness and femaleness. The public sphere is constituted by the context and content of addressing issues that differentially affect or that are differentially effected by gendered individuals interacting with each other. These interactions are mediated by culturally-defined ideologies and practices of male and female behaviour.

14 Valuations of gender cannot be understood in isolation from the cultural perceptions from which they emerge and into which the $y$ are embedded. These perceptions in turn, are rendered meaningful by individuals in their interaction with each other and in relation to the contextual realities with which they are confronted. In this sense, male and female roles are not mere dichotomies that are fixed, polarised or dually opposed to each other. Men and women's roles do not necessarily mirror each other in terms of the image and the imaged. These roles are mutually referencing in a 
relationally negotiated and complementary sense. Similarly, the form and structure of the private sphere is valued and upheld as such inasmuch as it is embedded in the public sphere and vice versa. In order to understand local conceptualisations of gender, dichotomies such as "dominant/dominated"; "public/private" and by implication, "modern/traditional", must be abandoned (Stamp, 1989).

Since the primacy of women in their own realms of authority within the private and the public sphere continues to determine the choices they make and influence the valuations of their status, WID should explore the reasons for this persistence rather than dismiss it (Stamp, 1989 :84). This paper suggests an alternative perspective that views women from a "gender dynamics" perspective that embeds the pre-colonial/ pre-monetarised economy in the contemporary capitalist one. In the past, gender dynamics ordered men and women's relations of kinship, lineage, residence, marriage systems, land succession, usufructuary rights, division of labour, local power/ knowledge and local networking patterns. Today, these dynamics have not been abandoned but have been adjusted, modified and reinterpreted to accommodate men and women's relations vis-a-vis the political/legal system, informal power structures, ethnicity and paternalism (Macharia, 1997).

An analysis of the transformations that occurred in the pre-colonial era would give a better understanding of the gender dynamics in the current capitalist economy. These dynamics influence the choices men and women make when negotiating their status with respect to each other and the society as a whole. Their gender valuations as well as their gauges of wealth and well being tend to shift in response to both traditional and modern stimuli (Bulow, 1992 :522). Accordingly. my critique embeds women in their pre-colonial/pre-capitalist past in order to outline some culture-specific valuations of their autonomy. It also outlines some of the extenuating factors that have stripped women of their autonomy and made them structurally dependent on men. I shall now illustrate my critique, based on data collected during my fieldwork in 1997 among the Gusii of south western Kenya.

The status of women in the pre-colonial Gusii society

17 The Gusii patrilineal, polygynous, and horticultural heritage is familiar and comparable to a large number of rural communities that have been described by various authors (Bulow, 1992 ; Francis, 1995; Oboler, 1994; Hakansson, 1987；1989). However, contemporary Gusii must in no way be regarded as a culturally homogeneous group. The Gusii, just as most locai communities in Kenya, are characterised by varied gradations of intra- and inter-social and cultural diversity. These variations may be attributed to their encounter with Catholic and Protestant missions, compulsory education, national administration, market encroachment, interaction with other ethnic groups and local or regional migration. In spite of this apparent heterogeneity, the Gusii tend to perceive and thereby distinguish themselves from other cultural groups, as being a homogeneous group with a common cultural heritage.

18 In the pre-colonial past, the Gusii organised themselves around a patrilineal structure whereby descent was traced through the male line. Marriage was virilocal, however, men were prohibited from marrying women from nearby. The clans were exogamous. Women were considered as being strangers in their husband's clan not only because they had to move from distant clans but also because they were ritually restricted from forming any lasting links with their own families. In a comparable study among their Kipsigis neighbours, men preferentially married from nearby clans. Kipsigis women 
were able to organise themselves into ritually and politically legitimate networks that were largely comprised of their own natal kin (Bulow, 1992).

Bridewealth was the token of marriage, as it transmitted ail rights in the woman' productive and reproductive capacities to her husband's lineage. Bridewealth severed women's jural links to their fathers and brothers, except in the event of divorce. However, it mediated a number of ritual obligations which compelled husbands to allow their wives to make occasion al visits to their own families. These visits were usually of a ritual rather than of an affective nature. Bridewealth transmission among the Gusii is unlike the one among their Luhyia neighbours, where it legitimised Luhyia women' status as mothers and wives in their husbands' clan without relieving their own fathers' and brothers' jural and ritual obligations towards them. In this sense, bridewealth strengthened rather than alienated them as daughters and sisters of their natal clan . (Hakansson, 1994).

Among the Gusii, the primary domestic unit was the compound (omochie), which comprised of a polygynous senior male (omogaka bw'omochie), his wives' hearth-holds (chinyomba) and his married sons and their respective wives' hearth-holds. Husband did not have a separate dwelling during their physically productive years however when they became old and weak, they were allowed to dwell in a hut (egesa) constructed as part of their first wife's property. Men who were not yet considered as being physically productive i.e. unmarried sons were also allowed to dwell in a separate hut (esaiga) constructed as part of their respective mother's property.

Historically, the Gusii shared a common language and cultural heritage but never acted as a unit (Hakansson, 1987 :30). Tracing their descent to a common ancestor, Mogusii, the Gusii society was organised around a maximally expanding lineage that. fragmented into semi-autonomous family units. Membership and belonging within these units was reckoned in terms of interlocking claims to land succession and ritual. : compensation (Hakansson, 1987). The ramifications of succession and compensation were traced in all levels of interaction namely, individual, family, lineage, clan and Gusii as a whole. The Gusii lineage system was also ordered around age sets whereby men and women who were circumcised in the same cycle formed a bracketed cluster of individuals. Spatial and social norms were gauged in terms of mutual reciprocity within and between age sets, in the production, processing and control of resources of the land. Wives were integrated into their husband's age grade and had to be accorded due respect, regardless of the fact that most of them were much younger that his age mates.

Since they were not necessarily comprised of individuals of the same age or sex, relations within and between age sets was fraught with tensions, competitiveness and power imbalances. Notwithstanding these internal age differences and external sexual distinction, both male and female individuals who were circumcised in the same year tended to perceive each other as being "those who gather together" (abagisangio).

Members of an age set considered each other as being equal in status and influence but had to defer to those senior age sets be respected those of younger ones. Positions of leadership and authority was accorded to those who succeeded in containing these inherent age set tensions, instilling social harmony and thereby promoting the interests of its members. These positions were delineated further on the basis of gender such that female age sets had to defer to those of their male counterparts, within an equivalent hierarchy. 
24 Access to land was reckoned in terms of male succession but absolute ownership did not exist. Land was regarded as belonging to the founding occupants, who then transmitted corporate custodial rights to ail the succeeding occupants. In this sense, land ordered their past, present and future relations. Male elders were accorded the ultimate authority and control in monitoring their descendants' relations with respect to the land. Their status was gauged in terms of their success in controlling their respective sons and in instilling mutual harmony and co-operation within and between their wives' hearth-holds. Similarly, sons' statuses was gauged in terms of their deference to their fathers and their success in containing tensions amongst their respective wives.

Women elders were also perceived as the custodians of the corporate land by virtue of their role in implementing and perpetuating the male elders' ancestrally derived voice of authority. Women who were past child-bearing age gained equal respect as male elders and were often consulted during decision-making process (see also Lambert, 1965). Female eiders were credited for chastising both men and women who failed to adhere to the prescribed norms of behaviour. Accordingly, they tended to be viewed as the moral and ethical guardians who monitored behaviour and meted out the sanctions that had been imposed by male eiders. They also tended to be viewed as confidantes and mentors by all newly married, childless and recently widowed in-married women. Male and female elders' spheres of influence in decision-making and control over resources were regarded as being simultaneously hierarchical and egalitarian. Accordingly, neither the male nor the female eiders could interfere with the other's sphere of influence or undermine their respective control and authority.

Fathers were charged with the responsibility of allocating land equitably amongst their sons and providing them with the necessary cattle to acquire their first wife. Thereafter, each son was charged with the responsibility apportioning their inherited land and cattle equitably amongst their wives'. This property, which was inalienable from the wives' respective hearth-holds became the heritable property of sons. All in-married were therefore accorded autonomous control and custodial rights over their sons' heritable property, which was inalienably attached to their respective hearth-holds. Since this property was viewed as a portion of the clan's heritable corporate holding, they had to defer to their husband and by extension, the agnatic clan elders' overarching authority over its distribution and allocation to their sons (Gluckman $1950: 195-9$, Oboler $1994: 342$ ). In this sense, sons acquired a major share of their inheritance from their father but through their mother's hearth-hold while wives acquired a major share of their property rights through their husbands' share of the clan's heritable corporate holding (see also Bulow, 1992). Fathers often reserved a tract of land (emonga) which was exclusively used by them to reinvest in successive marriages or to expand their sons' heritable holding. Wives and children were not obliged to work on this land since any food produced by their labour was automatically considered as being part of their respective hearth holds. Consequently, husbands had to rely on their own efforts and the willingness of their age-mates' and grandchildren to work on this tract of land.

27 The distribution of property within hearth-holds and the co-operation between the wives heading their respective hearth-holds, was considered as being relatively autonomous and mutually exclusive. This property not only formed the basis by which the male and female spheres of influence were determined, but also the way family 
members were oriented and later fragmented into semi-autonomous units. Relations between children of the same mother was strengthened by the mother while those between children of one father and different mothers was strengthened by the father. In this sense, the bond between children of the same father and mother was stronger than that of one father and different mothers. The latter cluster formed distinct and separate family grouping that was held together by the father. Once the father died, all these family groupings fragmented into semi-autonomous units that were held together by their respective mothers, but under the auspices of eldest sons or husbands' brothers.

Women were accorded due respect as the representatives of their fathers' and husbands' agnatic clan. They were also accorded due respect as the bearers and nurturers of potential lineage heads of their husband's agnatic clan as well as the producers and processors of grains and vegetables. So how the women themselves gauge their own statuses? Firstly, in terms of their ability to provide for the family's consumption and well-being as well as their custodial role to protect and expand their sons' heritable property. Secondly, in terms of their ability to promote their husbands' influence by being hospitable to his friends and relatives. Thirdly, in terms of their capacity to defer to their husbands' authority and maintain family solidarity. Relations between spouses and amongst wives was fraught with mutual conflict and competition for their shared and therefore, shareable resources. Wives' statuses was largely predicated upon their ability to contain the Inherent tensions embedded in their conflicting and contradictory roles as wives and mothers.

Valuations of women's autonomy were sustained by customary ideas relating to their status as "heads of autonomous hearth holds" in their respective husbands' homesteads. Men only acquired a residence in their youth (esaiga) or when they were elderly (egesa), hence husbands had to negotiate their habitation between their wives' dwellings (chillyomba). They were prohibited from entering wives' granaries or appropriating the land and cattle that was attached to their respective hearth holds. They were also prohibited from interfering with their wives' decisions on producing, processing and distributing grain for the family's consumption and well-being. Husbands' statuses were firstly gauged in terms of their ability to provide their wives with the means to fulfil these functions. Secondly in terms of their ability to contain any conflict between spouses or amongst sons for their shared and therefore shareable resources. Thirdly, their ability to ex tend their wives' hospitality to proximate kin and thereby forge bonds of affiliation that expanded their political influence over them. Fourthly, their ability to compensate for any shortfalls in their wives harvest that interfered with their capacity to feed the family or be hospitable 10 proximate kin.

Gender discourse tends to depict male succession and autonomy in allocating resources as contributing to a devaluation of women's status however, the converse is true in many cases. Women have a strong influence in determining the nature of male succession and allocation of resources since men can only gain access to land through their respective mothers' hearth-hold property. Similarly, husbands have a great affinity and loyalty towards their wives', primarily because of their custodial role over their sons heritable property and secondarily because of their ability to expand it. Men were and still are totally dependent on women for their livelihood and their future. Nowadays, husbands can purchase land elsewhere or appropriate an unreasonable portion of their heritable property as emonga and thereby legitimately curtail their 
wives' and sons' claims to resources. When they utilise their heritable property for cash crops, a number of men also tend to rely on paid labour both as a means of excluding their wives labour contributions as well as pre-empting their claims to the benefits accrued.

Extenuating factors that that stripped women of their autonomy

The colonial and missionary influence had a most damaging impact on women's autonomy. Colonisation, which coincided with the industrial revolution, necessitated a demand for natural resources for the industries back home (Kameri-Mbote \& Kiai, 1993). Since the subsistence economy of the colonised populace was both self sufficient and non-commodity based, the primary objective of the colonisers was to disrupt this self sufficiency. Initial1y, this objective was attained through the colonialists' concerted expropriation, usurpation and hoarding of land for cash crop production as well as the introduction of migrant and/or forced labour. However, by the 1930's and 1940's, this strategy had failed to disrupt the local economy and land began to be experienced as scarce or contested resource. The integration of cash crop trade in the local economy coupled with the introduction of taxes and land tenure laws, had the desired effect of disrupting their self-sufficiency.

The 1954 Swynnerton Land Reform Plan bracketed land into artificial boundaries and stipulated that any claims of ownership could only be legitimated by title deeds (Bulow, 1992 :534). These land tenure laws were greatly influenced by the Victorian and Christian family model, whereby the male household head was accorded an authoritative and paternalistic position as the "breadwinner". Men were accorded title deeds to ancestral land, thereby stratifying the previously malleable access to, use and control of the land into a fixated bracket of male ownership (see also Bulow, 1992). Gusii men's obligation and responsibility to accord women custodial rights over their sons' heritable property was compromised this western ideology of exclusive rights of ownership (See also Bulow, 1992 :535). The 1950's and 1960's was therefore characterised by a tendency of local male inhabitants to hoard or appropriate land belonging to their migrant kin, many of whom were absent from their homesteads for long periods. Land succession on the basis of fragmentation, coupled by a dramatic rise in population and a sharp decline in subsistence economy also contributed to the experience of land as a scarce and contested resource. This perceived or real demographic crisis was compounded by the dichotomies that started to be made by the colonial and post colonial governments and later by the development agencies. Local communities were stereotyped as being comprised of a "private", "rural", "poor" and "provincial" dominated population as opposed to the "public", "urban", "wealthy" and "progressive" dominant one.

In the Gusii context, the impact of assuming that the husband was the household head and breadwinner was a feminisation of his overarching authority and influence over his wives' hearth-holds. The wives' house property (chinyomba), which was exclusively their domain, was consolidated into the (emonga) which belonged to their husband. This consolidation had the impact of aggravating the inherent gender conflicts with respect to land allocation as well as the production, distribution and storage of resources. Husbands gained control over cash crops produced on their wives' hearth-hold property but were ritually denied access to it since wives retained their autonomous control over the crops stored in their granaries. Husbands who encroached on their wives' subsistence economy were accused of "eating their children" because they 
deterred their wives' capacity to feed the family. Similarly accused were those who felt entitled to hoard, lease, lend or sell land, since they impinged upon their wives' custodial rights over sons heritable property. Men's strategic impingement of their wives hearth-hold authority altered spousal relations from relative mutual autonomy to asymmetrical dependence. Similar accounts describe how men's and women's domains dissolved, thereby devaluing the mutual respect, complementarity and reciprocity between genders (Bulow, $1992: 535$ ).

Land commodification may have contributed to the structural invisibility and devaluation of women as heads of their respective hearth-holds but the underlying evaluation of their autonomy prevailed. Today, women continue to be viewed as custodians of heritable family holding despite the fact that men, as title deed holders are empowered by the law to override their legitimate, culturally-sanctioned claims to it. A number of husbands have started to resort to the law so as to legitimise their non legitimate encroachment into women's spheres of influence. Conversely, wives have. remained sceptical about seeking legal recompense from laws which they perceive as legalising (their husbands') illegality. According to some older informants, a number of women migrated to the urban centres to escape from this "non-legitimate" male control. There is scant data on how the Gusii women reacted to these gender transformations, however, similar accounts have been described by other authors (Wipper, 1985 :13 ; , Oboler, 1985 :173 ; Bulow, 1992 : 536 ; White, 1988 : 139-160).

The development of an urban capitalist economy and the imposition of a taxation system had the desired effect of disrupting any semblance of self-sufficiency by artificially inserting a need for money. Initially, the colonised populace was reluctant to engage in labour migration because it involved working as cooks, house-boys and farm hands, jobs which were typically associated with women. Moreover, the work was not only low-paid but it also compelled the labour migrants to be far away from their family for long periods of time. It is hardly surprising therefore, that labour migration was at first stimulated by force and only later, by new cash needs such as taxation, clothing, cash to purchase bridewealth cattle (Francis, 1995 :200). Most migrant labourers who worked in low-paid jobs on European farms and plantations became "squatters", living' in "reserve settlements" at the fringes of colonialists property. A small educated minority gained access to better-paid jobs as teachers, clerks and junior administrators in the emergent urban centres (Francis, 1995 :202).

Women who migrated to the urban centres engaged in various forms of commodified domestic labour. The various waves of women's migration tended to shift in response to the urban capitalist economy and the increasing dependence of local communities on commodity goods and services. White described women's migrant labour as a strategy in replenishing their men-folk's diminished labour capacities by , "feeding, entertaining and relaxing" them for a price (1988: 140). Since male migrants did not eat enough to marry or purchase long-term domestic services, these women filled the void by becoming "short-term wives" for a stipulated price. According to White, there were three waves of women's migration into Nairobi (1988: 139-142). Firstly, the watembezi (app.1900-1924) whereby women walked about (Swahili word, Kutembea- to walk) selling hot meals, snacks, bath water and beverages to male migrant labourers. Secondly, the malaya (app.1922-1939) who offered the same services in the privacy of owned or leased rooms (Swahili phrase "mali ya haya"- affluence/property from shame). Thirdly, the wazi wazi (app.1934-1946) whereby a number of the older, established 
entrepreneurs started fixing prices so as to limit the encroachment of younger migrants into their spheres of influence. This wave was characterised by open competitiveness (Swahili word wazi- open, exposed or indiscreet) between women migrants. The colonial government viewed these women's activities as "unhygienic" and "repugnant" and thus tended to severely monitor and restrict their movements (White, 1988).

The 1950's and 1960' s, triggered a new wave of women migrants, offering the three types of domestic services in the hope of capitalising on post-war benefits. The emergence of these women coincided with the government plans for recovery and reconstruction, Where by these women's activities started to be viewed as being problematic. This period was characterised by open militancy of women against the concerted aggression from the police and elders back home, to control their movement and cripple their economic power base (White, 1988). Women migrants risked being stigmatised as prostitutes, however, many of them were credited for investing in their sons' education and thereby, residually expanding their husbands' influence (see also Bulow, 1992). Since both the colonial government and the missionaries were organised around a male labour pool, there was a tendency to invest in sons education, as a measure of ensuring that the y got a salaried job and thereafter invested in the care of their siblings. This sons' preference also emerged from the tradition al valuation of daughters, as being destined for marriage and therefore, not in a position to ever engage in paid employment. Unfortunately, this male bias, coupled with the alien notion of male-headed homes, paved the way for elders and by extension, husbands and sons, to control all incomes of their womenfolk.

Access to mission schools was predicated upon conversion and a demonstrable commitment to denounce and disassociate from "barbaric" customs such as circumcision, bridewealth, polygamy and wife inheritance. These customs formed the basis by which women derived their hearth-hold based autonomy, thus women tended to be very sceptical about conversion. Nonetheless some women opted for conversion firstly, as a means of enabling their sons to get married without the attendant constraints of bridewealth transactions. Secondly as a means of detaching themselves from the custom of widow-inheritance that legitimised the competing family interests in their productivity. And thirdly, as a means of becoming accepted into the income-generating networks that were funded by the missions. Most Gusii women shied away from conversion and only started accepting missionary education in the 1950 's and 1960's. When one wife in a polygamous home was converted, the others viewed her actions as a form of betrayal because it afforded her an unfair advantage over them. This was particularly the case when the converted wife, as the officially recognised spouse, took advantage of her position to promote her own interests al the expense of her co-wives.

Dramatic changes in rural-urban linkages also contributed to the loss of women's autonomy. Women migrants attained a measure of autonomy as traders and property owners in the urban centres. The colonial policy that promoted male labour migrations 10 plantations, however, compelled rural women to take over farm responsibilities of their absent men-folk (see also Bulow, 1992 ; Francis, 1995). Cash crop production in the country declined sharply as a consequence of women's tendency to prioritise subsistence over cash crop production. The type of cash crops that women cared for was limited, and restricted to female are as of economy (grain and vegetable gardening) 
and investment (children's education). The 1950's and 1960's were characterised with reverse migration whereby migrant men, armed with title deeds, took over from their wives and prioritised cash crop production at the expense of their wives' subsistence economy. Men started to appropriate land that was allocated to subsistence, forcing women to provide for consumption in ever-shrinking fields. Moreover, wives' labour contribution to the cash crop production and processing increased with little or no financial returns from its trade. Focus on cash crop production and trade was also characterised and shaped by external influences such as market encroachment and urbanisation.

The creation of high-wage sectors during the colonial era and the stabilisation of the labour market in the post-independence era triggered a wave of rural-urban migration. The urban sector was dependent upon a stable rural cash crop economy which in turn was expected to benefit from the dynamic links of wage employment and farm investment (Francis, 1995 :201). Conversely, most farmers regarded land primarily as means of survival and thus tended to invest in cash crop production and trade only inasmuch as it did not interfere with their wives' subsistence horticultural economy. Secondarily, land was regarded as being their sons' inheritance hence cash crop production and trade tended to be viewed as a means of expanding their sons' heritable holding rather than the accumulation of profit. The benefits accrued from cash crop trade as well as the remittances from sons and daughters who had migrated to the urban sector was invested in consumption and education of their siblings rather than on farm expansion (Francis, 1995 :201).

41 The falling urban real wages during the 1970's economic crisis coupled with the negative impacts of SAP's triggered a new wave of reverse migration to the rural area. This put a strain on rural-urban linkages, that compelled farmers to prioritise on the production and trade of subsistence crops. The combined effect of real (overpopulation), structural (ruralisation, land hoarding) and virtual (land succession based on fragmentation) demographic crises have rendered cash crop production in the rural sector as a non-viable investment (Francis, 1995). The current decline in cash crop trade is not only affected by the micro-economy of "production for survival" but also indirectly by macro-economic issues such as corrupt bureaucracy, surplus extraction and unequal trade terms. Similarly criticised is the fact that farmers are encouraged to produce crops that are not conducive to their needs, or on land that is not suitable for its production. Even in areas suited to the production of higher-value cash crops, farmers are handicapped by poor infrastructure, lack of appropriate technology, long distance from the co-operatives (Macharia, 1997).

The Kenyan economy is largely dependent upon the pace and pattern of the agricultural sector, which ideally should pro vide two-thirds of its export (Mach aria, 1997 :23). The fact that it has no substantive minerals for export and the industrial sector is still forming, implies that the economic crisis is predicated upon the declining agricultural production. Paradoxically, research seems to indicate that over the years, the full potentiality of the land's agricultural capacity has been poorly exploited (Francis, 1995). The government is less concerned with addressing issues of individual ownership than it is with the diminishing percentage of the land that lends itself to agricultural production (Macharia, 1997). This concern is triggered by the fact that less than $20 \%$ is arable and more than $40 \%$ is classified as being non-conducive to agricultural production (p.23). Moreover, only 19\% of the arable land is free from 
inherent limitations, much of it in the hands of a few financially and politically powerful men and women (Sigot, $1995: 6$ ).

The second fallacy : the local mechanisms of development

The second fallacy is founded on the assumption that women's contribution to development can only be assessed in terms of their productivity and reproductivity as mothers and wives. WID tends to assess women's integration into development in terms of their contribution family welfare. Its strategies are structured around existing and/or emerging women networks. The ultimate goal of the se strategies is to reorganise these networks in such a way as to enable its members to maximally expand their productive and reproductive outputs. WID promotes women-specific, income-generating projects so as to alleviate a number of constraints that are considered as being a deterrent to their efficacy and efficiency. It not only obscures the existence of women's local mechanisms of development but also has the propensity of stereotyping them as being passive. This stereotype is echoed in the colonial literature that tended to depict colonised women as being "muted", "subordinated" and "dependent on men" (Callaway, 1984). Contrary to these stereotypes, the Gusii illustration indicates that women were viewed as being fully autonomous and active social facilitators.

In the 1950s and 1960s, women migrants who had contributed to family welfare through prostitution, were literally harassed off paved streets to create "desirable residential areas" for the emergent local bourgeoisie (White, 1988: 142). Similarly victimised were those who rejected conversion as well as those who rebelled politically against the colonial government. Missionaries stigmatised these women as being prostitutes while colonialists burnt down homes and farms of women activists who had supported their men-folk during the pre-independence political struggles (Mugo, 1975). The colonial government, in the guise of ridding the urban centre of "unsanitary conditions" and assisting families to cope with the negative social and economic impact of the political unrest, initiated a concerted effort to address women's issues. They sought to deconstruct women 's tradition al roles as wives and mothers and thereby deflate their publicly articulated incentive to support their men-folk. This concern was shared by missionaries who scorned local women's "excessive sexuality" as well as local eiders who felt that their militancy and activism was loading to the neglect of the farms (Oduol, 1993).

The government's strategy for curbing women's prostitution and political activism was to lure them into the colonialists' wives' clubs that existed at the time. Financial and trade incentives were used to encourage club membership and thereafter, co-ordinate the disparate efforts of women's networks to form an umbrella organisation called Maendeleo Ya Wanawake Organisation (MYWO). This organisation, promised its mel1lbers subsidised training in income-generating arts and crafts skills, that were designed to alleviate some of their wifely and mothering constraints. However, membership turned out to be a double betrayal when both the conditions for membership and the nature of the prolllised training fell short of their expectations. Membership, on the one hand, was privileged to those who had collaborated with the colonisers by fabricating or betraying political activists. On the other hand, training was focused on the attainl1lent of non-market oriented welfare skills such as home-making, child care, nutrition, hygiene and less in market oriented trade skills such as arts and crafts (Khasiani, 1993 ; AAWORD, 1995). 
After independence in 1963, the government supported MYWO's mobilisation of women networks primarily because it realised their value as a source of cheap wellorganised labour for nation-building (Nzomo 1993 :138). Secondarily, because of the continued interest of the British in funding the clubbing activities that they had initiated. The underlying motivation for the government's endorsement and support of MYWO was popularly viewed as a political strategy to gain access to these donor funds (Khasiani, 1993). In order to dissociate MYWO from the negative connotation inserted by the colonialists' wives' clubs, the government introduced its own umbrella organisation in 1964, namely, the National Council of Women in Kenya (NCWK). It offered political incentives to the NCWK, thereby formally defining its public role as being distinct and separate from the MYWO's welfare role. The NCWK was co-opted by the government to represent the paradigmatic shift of integrating women in public affairs and thereby attract donor funds. The NCWK prioritised the government agenda, on the understanding and in anticipation of the fact that some of its members would be granted key political or public positions (Nzomo, 1993).

The GAD framework of the "gender-focused" development was ushered by the economic crisis that was prevalent in the 1970's. This period coincided with the World Bank and IMF imposition of SAPs as "the only reliable path to development". The impact of SAPs was a dramatic turnaround in capital accounts whereby the net transfer to the developing countries fell from \$US 44 billion in 1980 to minus \$US 63 billion in 1989 (Woestman, 1994 :5). Countries like Kenya which had become so dependent on the export of cash crops, were severely affected by the depressing trade and capital climate in the 1970s (Macharia, 1997 :29). Il was faced with external debt it could not service, severe inflation, deteriorating economic output, trade and budget deficits and an inability to attract development funds. In order to be eligible for the shrinking foreign investment, loans and aid, the government had to downsize its inflated civil service ; devalue its currency; allowing the market to operate freely without price controls and subsidies; curtail the monopoly of agricultural boards to purchase, process and market cash crops and cut back its subsidies in health, education and social amenities (Macharia, 1997 :29-30).

In the 1980's it was not enough to say that women had to be integrated in development, but rather that they had to be integrated into the SAPs solutions to the economic crisis (Woestman, 1994; Snyder and Tadesse, 1995). The World Bank claimed that "development and growth arc best served when scarce public resources arc invested in women, where they yield the highest economic and social returns" (Woestman, 1994 : 10). In response to this endorsement by the World Bank, women started to be taken seriously by policy-makers, strategists and donors. GAD advocated that women needed to have "wider control over and access to" political power in order to achieve social and economic development that was geared towards human needs (Schuurman, 1993 : 173). Women's daily struggles, such as food prices, cost of living, drains to health and education, lack of social services evolve around these needs. Since the se needs had become politicised through the SAPs, both western and local feminists claimed that the y needed to be addressed politically. Lack of "empowerment" was viewed as being synonymous to women's struggles for survival since both tended to permeate into and order relations in the home, the state and the workplace (Schuurman, $1993: 173$; Moser, 1989). 

positive signs of economic recovery. Paradoxically, it is not likely to fulfil some of the prescribed criteria pertaining to good governance, market liberalisation and debt restructuring without this external support. Currently, people's "quality of life" expectations have been reduced to an ail time low due to the SAPs' imposed unemployment, inflation, breakdown of health, education, social services and infrastructure (Mach aria, $1997: 30$ ). Criticising the SAPs, UNICEF asserted that "hundreds of thousands of the developing world's children have given their lives to pay their countries' debts" (UNICEF, 1990 :26). Conversely, the World Bank insists that "investing in women at this critical phase raises economic productivity, promotes a more efficient use of resources, produces significant social returns, improves child survival, reduces fertility and has considerable intergenerational payoffs" (Woestman, 1994 : 10).

The 1980's triggered a wave of development pessimism that was crippling theorists, donors and activists (Schuurman, $1993: 124$ ). This was exacerbated by a rising tendency to view development in terms of donor and recipient impasse, stagnation and fatigue. The SAPs, fraught with contradictions and negative (social, economic and political) repercussions, were also blamed for the prevalent development impasse. Western and local feminists inherited this development vacuum, which was diffused with increasing demands for sustainable development and economic recovery. They were faced with the impossible challenge of stimulating support from policy-makers and don ors who seemed to have an increasingly diminished interest in development. The impact of SAPs coupled with the drastic recession of external stimuli, also made it impossible for GAD to stimulate governmental commitment to their proposals. Development theorists, activists, policy-makers and donors as well as local political and elite bourgeoisie seemed to have just shifted the burden of sustainable development and economic recovery to their women-folk.

51 Kenya's stagnant and/or deteriorating economy has influenced the "gender-focused" development in the following manner. Firstly, it is preoccupied with short term policies aimed at keeping the national economy stable in terms of debt and as such, can not take the intermediate or long term policies promoted by "gender-focused" development into consideration. Secondly, it is preoccupied with seeking solutions to the widening gap between the rich and poor which the latter are unlikely to bridge, whatever development strategy they follow. Thirdly, "gender-focused" development tends to be viewed by the government as a stopgap solution to the current impasse, a plausible but yet untested alternative and a "wait and see" approach. It is hardly surprising therefore, that Kenyan women's involvement and participation in development only amounts to a shaky enterprise with respect to the local political and elite bourgeoisie.

52 In the 1980' s, the WID and GAD approaches started to be criticised by local feminists as "a cheap delivery system" for SAP's (Snyder and Tadesse, $1995: 13$ ). Western feminists' attempts to integrate local women in development was viewed as being superfluous since they were already well integrated, often into more work and worse conditions (Schuurman, 1993 :171). Also criticised was their tendency to ignore the conflicts of interest between men and women and within women's groups (Schuurman, 1993 :173). Neither men nor women could not effect any real legislative changes in sexual equality since there were no indicators to monitor or measure them. Moreover, there was a 
general reluctance amongst government officials, development bourgeoisie and even the impoverished men to redistribute power to women. Local feminists claimed that "equity" without any local economic growth or gain in power for women was self contradictory (Moser, 1989).

The non-elite women for whom the "gender-focused" development is targeted, also tend to regard it with a measure of scepticism rather than enthusiasm, derision rather than hope and criticism rather than co-operation. Nonetheless, most Kenyan women concur with the fact that "gender-focused" development has enabled them to raise issues that had been ignored by both the colonial and the current government. As mentioned earlier, women had already started to mobilise themselves into politically-oriented groups during the pre-colonial and colonial eras. MYWO, under the leadership of Margaret Kenyatta (the first president's daughter), organised the Kenya Women's Seminal' (1962 and J963) and the East Africa Women's Seminal' (1964). The purpose of these seminars was to sensitise women about the important role they had to play in the newly independent Kenya. Women were encouraged to organise themselves in registered groups so as to raise money to fund their job/skill training and children's education (Snyder and Tadesse, 1995 :25). The post-independence NCWK's euphoria was short-lived because, not surprisingly, the government failed to honour the political incentives it had promised its members. However, the men besides whom they had fought during the struggle for independence and with whom they had worked in various nation-building projects, received due political recognition for their efforts.

Since the 1960s, Kenyan women have organised themselves into groups through which they articulated their social, political and/or economic ideals. Most of them tended to adopt a harambee (Kiswahili term meaning lets pull together) "self-help" approach which is described in this article as being an "endogenous socialist". I have described it as being "endogenous" because it emerges From and is embedded in local cultural practices of pooled labour. It is also "socialist" because it emerges from and is perpetuated by local communitarian ideals of working together for the betterment of the collective whole. The harambee approach is encapsulated in the public sphere of politics, development, economic affairs as well as the private sphere of familial integrity and local participation in community affairs.

harambee mobilises individuals within ail the units that make up a society, to "pull together" both for financial as well as moral support. Any Kenyan, regardless of class, gender, religious beliefs or political orientation, can apply for and get permission From the appropriate local government representatives to initiate a harambee project or a fund raising drive. harambee is viewed as a guiding principle for mobilising relatives and friends to construct a house, organise familial feasts (birth, wedding, graduation) and settle outstanding bills (school fees, medical bills, funeral expenses). It also mobilises members of a community to contribute similarly towards the achievement of public goals that have profound implications on their private life. These goals include the construction of housing units, schools, health centres, roads, dams etc. Nowadays, politicians also adopt the harambee concept to mobilise families, communities, constituencies and the country as a whole, to counter the negative effects of SAPs on housing, education, health, food security. Most Kenyans, despite this highly publicised and politicised image, actively and voluntarily contribute their money, free time, expertise and labour to these projects.

The homogeneity of women's networks. 

divided into three main clusters. Firstly, the networks that are forged to alleviate personal difficulty, secondly, those that are forged to promote collective interests and finally, those that are forged as income-generating co-operatives. The first cluster is basically consistent with the Gusii traditional networking whereby women radiated to other women to mutually support each other and thereby affirm their shared joys and sorrows. These networks emerge in response to women's increased pressure to fulfil their subsistence and domestic obligations in the face of diminishing family labour and economic contributions. They are particularly important in enabling women who migrate to urban centres and are cut off from their extended family support, to cope with isolation and the attendant social marginalisation due to poverty and domestic violence (Kinuthia, 1993 :39).

This networking strategy, which is synonymous to the harambee approach, is adopted by ail Kenyans irrespective of gender and class distinction. However, most women and men who adopt this strategy do not necessarily register their group as an NGO. These networks, which comprise of loosely structured groups of friends, neighbours and members of a common cultural background are usually privately organised. Members of common ethnic and/or religious affiliations sometimes form registered NGOs e.g. "The Gusii Catholic Women Association (GCWA)". Nonetheless, the main reason that draws them together is a "survivalist" need to cope with their mutual suffering rather than ideological, religious, political or even cultural reasons. 
60 networking whereby a number of influential elderly women contributed to the activities of other women for pragmatic and opportunistic reasons rather than "survivalist" ones. Nowadays, the encroachment of market integration and the reality of existing in abject poverty has compelled many of women to engage in a variety of informal income-generating activities. Their participation in these activities is utilitarian inasmuch as the collective projects they promote, serve the interests of their husbands and children, thereby residually trickling down to each of them. These projects include on a macro-level, formal fund-raising and voluntary labour contribution for the construction of schools, health centres and communal facilities. On a micro-level they include fund-raising for fees, medical bills and the creation of informal trade opportunities in the community (Kinuthia, 1993). The motivation for membership and participation within these networks usually emanates from charitable ideals but also encapsulates, to a greater or lesser extent, social and political activism.

This cluster is usually formalised into registered NGO's and "self-help" harambee groups. The interests of the members within these networks range from tangible goals such as those mentioned above, to abstract ones such as population control, environmental protection, human rights intervention, equal opportunity lobbying etc. Groups engaged in achieving the se abstract goals usually comprise of a selective number of female academic and political elite. In the aforementioned Gusii NGO, these women are referred to as "the mothers-in-law" (chikorera) because they usually have senior positions in either the MYWO or NCWK. Paradoxically, women who represent their groups in these umbrella organisations, are looked down upon by members of the NGOs they represent. They are regarded by these women as being "those who (think they) are worldly and wealthy" and "those who have the time and money to engage in philanthropic and political pursuits. They are often denigrated by the women they represent as being "bigger than men", "eating their sons" or "emasculating their husbands" because of their propensity of encroaching on male spheres of influence (Bulow, 1992). Conversely, the y tend to view themselves as being social facilitators engaged in one way or the other, in the [male dominated] theatrics of policy-formulation and decision-making. Their agenda and mission statement usually coincides with western feminists ideals for the promotion of women's emancipation, autonomy, empowerment and equality.

This third cluster is similar to the Gusii traditional networking whereby pooled labour and mutual exchange of goods and services enabled individual women to produce agricultural surplus. The invaluable information they gleaned from other women enabled a number of them to improve their economic, political and social status and by extension, that of their respective husbands and sons. Similarly, this cluster of networks can best be described as an amalgamation of loosely structured sub-clusters of women, drawn together by a common interest and yet at the same time, fraught with internal conflicts, divided interests and mutual suspicion. Its members are acutely attuned to the on-going shifts in donor funding preference. They keep abreast with the global ebb and flow of gender-focus and thereby design their project proposals accordingly so as to maximise their chances of eligibility for funding. This form of networking, which has been described as public service contracting, usually meets an important donor need of delivering services for long-term goals, in short-term project funding bursts (Korten, $1993: 17$ ). When funds run out or when the service has failed or

Bulletin de I'APAD, 20 | 2000 
been fulfilled, these networks tend to disband or seek alternative projects in response to new donors needs (Kinuthia, 1993).

Structured around registered non-profit NGO's or co-operative groups, these networks tend to have a formal leadership hierarchy that is comprised of a chair-person, treasurer and secretary who make up the administrative board. This board is elected annually or bi-annually by members, whose membership to the group is conditional on the payment of a stipulated fee. Publicly, these networks usually tend to maintain a facade of having homogeneous interests so as to be eligible for funding. However, in practice, they are often characterised by their heterogeneity in membership, ideology and flexibility to respond to donor preferences. Although they are designed for income-generation, most of these NGO's are structurally non-profit. Many of them incur such high overhead costs, that the profit margin is minimal and the financial returns that trickle down to its members are insignificant. The reason for this disproportionately high costs is usually blamed on corruption and mis-appropriation of funds by one or more of the board members. Also criticised is the lack of cohesive ideology and the general ignorance or powerlessness of a majority of its members. Donors who impose stringent conditions for funding and compel women to strive for unrealistic and impracticable goals, have also contributed to the diminishing returns of these networks (Kameri-Mbote and Kiai, 1993 ; Kabira and Nzioki, 1993).

These second and third clusters of women networking are represented by the two umbrella organisations, namely, MYWO and NCWK. These organisations are often depicted in discourse as being on opposite ends of a continuum (Kameri-Mbote and Kiai, 1993). The NCWK on the one hand, tends to represent urban-based networks of women elite, that focus on women's empowerment as well as environmental and humanitarian issues. On the other hand, MYWO tends to represent rural-based "grass-root" networks of impoverished, non-elite women. The NCWK represents the most outspoken women's groups, some of which have been credited for their success in challenging government decisions about the environment and human rights. The most celebrated case is the Green Belt Movement's battle and success in stopping the government from erecting a skyscraper in the middle of one of the largest recreational parks in Nairobi. Conversely, the MYWO not only shies away from controversial issues but also dissociates itself from the NCWK's radical stance and opposition to unfavourable government policies.

Umbrella organisations such as the MYWO have been described elsewhere as being "an extension of governmental authority, created to promote its agenda, and by implication, the interests of those who control its instruments of power" (Korten, 1993). Such organisations, which are known by the anomalous term "governmental non-governmental organisations (GONGO), are also created in response to the dominant development discourse and donors' funding interest. GONGO's are co-opted by the government so as to facilitate its indirect usurpation of donor funds hence they tend to be viewed as a compromise that promotes ail the involved parties' interests. In the Kenyan context, umbrella organisations such as NCWK and MYWO are good examples of GONGO's whereby the former is criticised because of tendency to challenge the government while the latter is praised because of its conformity.

Women's networking strategies are not so clear cut hence it is not unusual for women to seek membership in a variety of registered networks which are affiliated to either MYWO or NCWK. Similarly, it is not unusual for members of unregistered networks to 
seek successive and concurrent membership to a variety of these registered NGO's. The heterogeneity of women's networking strategies is therefore characterised and shaped by its members compulsive engagement in a repertoire of development discourses that sometimes contradict each other. This propensity for multiple membership can be viewed as a measure of challenging three levels of influence. Firstly, the self-acclaimed authority and spokesman-ship of women elite that is viewed by the poor, illiterate and the rural women as being equally and sometimes worse than male influence. Secondly, the non-legitimate intrusion of men into the female spheres of influence that has paved the way for their usurpation of women's autonomy and increased responsibilities they have to shoulder. Thirdly, a desire to cash in on the donor funds so as to raise capital to invest in their families' subsistence, create or expand their businesses and/or promote their feminist, idealist and/or political interests.

The valuation of the women's bureau in the context of "gender-focused" development The fourth fallacy pertains to the so-called "gender-focused" development successes. A case in point is the introduction of Women's Bureau (referred to in this paper as WB), which is presented as being one of the most important triumphs of both the WID and GAD interventions. The WB is viewed by man y women who feel excluded from its benefits as precipitating a repertoire of betrayals that are toted as triumphs. Similarly, the findings of this paper seem to suggest that rather than being a banner of success, the WB epitomises and perpetuates the afore mentioned fallacies. These in their turn, have singly or in combination with other related factors, contributed to the continued failure of "gender-focused" development.

The aftermath of the "UN end of the Women's decade" conference that was held in Nairobi in 1985, triggered a number of national actions such as the Forward Looking Strategies to the Year 2000, the Plan for Action and the Programme for Action. These actions called upon governments to "identify the impact unemployment has on women; provide employment equity programmes ; provide equal access to ail jobs and training for women; improve conditions of the formal and informal labour markets; recognise and encourage the small business initiatives of women; provide and encourage the establishment of child-care facilities ; and encourage, through education and public information the sharing of responsibilities for child and domestic care between men and women" (O'Neal, $1986: 20$ ). The engagement NCWK's members in these actions, coupled with their attendant lobbying and activism in demanding for favourable government policies increased public awareness of women's issues. This in turn triggered a dramatic rise in MYWO's NGO registration as well as a more concerted articulation of "gender-focused" development.

The co-ordinated NCWK and MYWO actions led to a breakthrough in 1984, when the government created a Women's Bureau (WB) sector within the Ministry of Culture and Development (Khasiani, 1993). The WB's governmental mandate was to "formulate policies affecting gender issues and women' $\mathrm{s}$ overall integration on society; co-ordinate and harmonise women's activities performed by government ministries and NGO's; collect and analyse data on expatriate project and donor proposals; co-ordinate, monitor and evaluate women's projects ; provide the government and don ors with feedback on on-going projects; train, sensitise and mobilise women's "self-help" initiatives" (Khasiani, 1993: 124). The government also responded by revitalising the mandate of MYWO with political and economic incentives. Emboldened by the governmental stamp of approval, MYWO withdrew its affiliation from the NCWK 
taking with it the bulk of the grass-root organisations that had remained loyal to the organisation over the years.

The creation of the WB coincided with MYWO's affiliation with the ruling party KANU, which thereafter adopted the new title KANU-MYWO. According to Khasiani, the government encouraged the co-operation between KANU-MYWO and the WB so as to hasten the mobilisation and registration of women into groups (1993:124). Thus while the latter was mandated to register, the former was charged with the responsibility of mobilising its current and emergent members. The government shifted its support from NCWK to MYWO because the latter was already established at the rural sector and was viewed by donors as being more representative of the grass-root reality.

Conversely, it tended to view the NCWK as a threat to its hegemony, which comprised of a well entrenched male majority. NCWK's combatant approach was simultaneously its source of power and autonomy to resist external influence as well as the reason it failed to stimulate representative grass-root participation. Most of the registered NGO's affiliated themselves with MYWO primarily because of its success in attracting both donor funding and governmental endorsement. Women were disillusioned by the complacency and non-assuming attitudes of the MYWO, however, they were even less impressed by the demanding and aggressive attitudes of the NCWK (Khasiani, 1993).

Today, the government's attitude towards the KANU-MYWO is no different from the one that was adopted by the colonial one towards their clubbing activities in 1952. The organisation, which was created to suit the interest of the colonial government, has been co-opted by the current one in a similar manner, so as to promote its agenda. The government tends to stifle the agency of KANU-MYWO's leaders by paying "lip service" to their proposed social, economic, legal and political reforms but resorting to delaying tactics when it comes to implementation. Other strategies include making token changes, installing figurehead organisations, shelving/postponing urgent documents or refusing to comply with women's legitimate demands for legal and political reforms (Khasiani, 1993 ; Oduol, 1993 ; Omosa, 1995).

Politicians often publicly ridicule key representatives of KANU-MYWO and NCWK e.g. in his inaugural speech at the "East African Women Parliamentarians' Conference (8th March 2001), the president blamed women for not achieving the goals that they had set themselves. He is cited in the papers as saying "you can achieve more! can get more! But because of your little minds, you can not get what you are expected to get! " (Daily Nation, 2001). These comments fuelled the inherent dissent among members of KANU-MYWO and those of NCWK whereby the latter accused the former of consorting with the government in a manner that invited such a contemptuous reaction. NCWK also accused the KANU-MYWO leadership structure as being comprised of "wives, daughters and sisters of politicians" who have to succumb to the government's every whim (Khasiani, 1993). Similarly accused were the politicians who offered financial and political incentives when they needed KANU-MYWO's assistance but failed to honour their promises when they felt that their patronage had ceased to be functional to their needs (Khasiani, 1993).

An overview of the WB's GAD-based initiatives

74 The WB, implemented the "Forward Looking Strategies" in accordance with the GAD framework. It is the officially recognised body responsible for co-ordinating NGO's that are committed to raising women's status from welfare to empowerment. It promotes the activities of NGO's which are engaged in lobbying for the ratification of laws that 
impinge upon women's rights. It also subsidises "legal clinics" which offer women free legal services. It co-ordinates the activities of NGO's which provide women with loans that would enable them to engage in informal trade and small-scale businesses. And finally, it co-ordinates the activities of NGO's engaged in raising women's awareness of their voters rights or subsidising election expenses of aspiring politicians.

Women and the law

A survey conducted in 1981 by Women's Rights Awareness Programme, determined that women's non-use of the legal process was due to the fact that most of them were ignorant of their constitution al rights. Accordingly, the Public Law Institute (PLI) was established to provide legal support to women, whose ignorance or poverty had structurally excluded them from legal representation and recompense. It was also aimed at advocating for the ratification of laws that impinge on women's rights such as family laws concerning marriage, divorce, child support/custody and pro pert y laws concerning succession and inheritance (Kameri-Mbote, 1995. The PLI is viewed as the main channel through which the WB intervenes on behalf of NGO's engaged in women's legal empowerment, public interest litigation, legal education, legal aid and research. However, politicians usually respond to its recommendations with counter-accusations that these are contrary to the customary law.

In a 1985 parliamentary discussion on the status of women in marriage, politicians claimed that "a husband has a right to discipline his women" (Amnesty International, 1995). Ministers, in the guise of protecting the sanctity of the institution of marriage, objected to any external interference with a husband's right to chastise his wives and daughters. Accordingly, they failed to pass the Marriage Bill that accorded equal rights to spouses in matters concerning the allocation, control and authority over matrimonial property, child custody, divorce and inheritance. They also turned down the PLI's petition to ratify laws that prevented women from seeking divorce in proven cases of adultery. Customary laws on polygamy tend to override women's objection to their husband's successive marriages (Kameri-Mbote, 1995). However, polygamy as it is practised today, is no different from having a series of mistresses who are committed to one man. These women are neither accorded a respectable social status nor guaranteed any legal security (De Temmerman, 1995; Odhiambo-Oduol, 1995). Men reinterpret customary law so as to justify their (often forcible) usurpation of their womenfolk's earnings and non-legitimate impingement of their rights to property and inheritance (Omosa, 1995).

Women in business

The Kenya Business and Professional Women's Club and the Association of African Women in Research and Development were created to stimulate women's participation in high salaried sectors of the economy. The WB established the Kenya Women's Finance Trust with the Women's World Banking as the guarantor. The Trust is mandated by the WB to facilitate women entrepreneurs with a credit guarantee scheme. It finances small scale ventures and loosely structured commercial and service businesses that are otherwise not funded by commercial banks and related financial institutions. It also invests in the managerial training of women interested in engaging in such small scale trade ventures. In spite of the apparent success of the trust in subsidising the necessary training and administering the necessary loans, its internal administration has been described as being amateur, corrupt and non-professional (Omosa, 1995). 

sustainability and economic viability of the funded businesses as well as the disproportionate rate of loan non-payment. Its inherent female-bias has also been criticised, particularly when it excludes men who are equally qualified to benefit from it. Some of the se men include those who engage in small scale and informal businesses that have in the past been associated with women. These businesses are popularly referred to as "hot sun" (jua kali) because they are conducted in the open-air rather than enclosed markets (Macharia, 1997). They include furniture-making, dress making, hair-dressing, meat roasting, [vigilante] security from government repression, the sale of second hand clothing and recycling of scrap metal in the market (1997 : 35-49).

Women in politics disproportionate representation of women in politics. A survey conducted by the National Committee on the Status of Women determined that this disparity was due to women's ignorance of the voting procedure. The WB established the Women's Voters League and the National Committee for the Advancement of Women-KANU 92, to mobilise women's engagement in politics, by raising their awareness of voting procedures. These organisations were also established as a measure of providing moral and financial support to aspiring women politicians (Oduol, 1993). However, they fail to appeal to the majority of the women to whom their services are targeted. They have been criticised for their asymmetrical representation of impoverished, rural or illiterate women. Also criticised is their female-bias which excludes an equally compelling number of men who are just as ignorant of their voting rights as the women they represent.

An overview of WB's WID based initiatives

The WB is also the official co-ordinating body through which WID policies are implemented and don or funds channelled to NGO's. Its activities are supposed to cohere with those of the government strategy for the implementation of the "District Focus for Rural Development" that was established in 1985. Consequently, it monitors and evaluates NGO proposal for expatriate recruitment and donor support on behalf of the District Co-ordinating Committee (Nzomo, 1997). The WB, working in conjunction with researchers, donor agencies and government official, determines the economic viability of women's income-generating projects. It is on the basis of the top-down recommendations of these four bodies that decisions are made as to whether an organisation needs 50 chicken per 100 women or 1 pig per 20 women to attain the desired bottom-up solutions.

81 The WB targets impoverished, rural-based illiterate women, singling out female-headed families as its priority. Adopting the Household Unit Principle (Ventura-Dias, 1985 : 157) the WB assumes that these families represent the most vulnerable group of women. The HUP presumes that a household is an undifferentiated unit wherein women can improve their lot and have full autonomy in what they produce (Stamp, 1989). The underlying assumption is that these women would be able to market their products and expand their production by determining their own reinvestment options (Ventura-Dias, 1985). In reality, ail Kenyan families tend to be structured around the woman or women who provide for their subsistence and welfare. However, a distinction is made as to whether a woman is married or not and whether she heads the family as the biological mother or female guardian such as co-wife, sibling, aunt or

Bulletin de I'APAD, 20 | 2000 
grandmother. This in turn, is influenced by such considerations as the male members of nuclear or extended family networks who are ritually and jurally obliged to censure that these women are able to fulfil their role. Female-headed homes are therefore considered as being male-controlled, by men who may or may not be in permanent residence but who are nonetheless, legally obliged by the law to act on women's behalf.

Projects that target female-headed families tend to fail primarily because of a lack of consensus in their definition and scope. Secondarily, they tend to aggravate inherent claims to women's productivity whereby their individual share is minimal and their status worse off. They fail to take into account the fact that women have to share their money amongst the various immediate and extended family who have a vested interest in their welfare. Moreover, when they focus on women in the rural sector they tend to overlook the fact that these women's activities are influenced by relatives who also feel entitled to a share of the benefits, man y of whom are widely dispersed in various parts of the country. The WB, in countering these negative repercussions of targeting female-headed families in the rural sector, tend to recruit men or male representatives in managerial positions. In this sense, the household continues to be perceived as an important economic unit to determine the efficacious use of the allocated appropriate technology. However, men arc depicted the legal representatives of the women, who in their turn are the ultimate users and beneficiaries. The WB has the propensity of inserting an artificial gradation of recipients whereby they receive the funds and allocate it via (male) extension workers. These in their turn, impart the necessary technological know-how (expertise) and control of user rights to male household heads. Husbands therefore manage the equipment (implementers), determine how wives should use it (facilitators) and arc consulted by WB representatives about the progress (project evaluators) (Stamp, $1989: 153)$.

The WB promotes income-generating projects are designed for poverty-alleviation and the provision of basic welfare needs and not for economic expansion. Few of them succeed in generating income let al one stimulating economic growth. This failure may be attributed to a conceptual error in the formulation of these projects but unfortunately, tendency is to shift the blame on the women for whom the y are targeted. Since many of them are illiterate, evaluators tend to blame project failure on their ignorance and their Jack of the technological know-how. This obscures other related issues : firstly, the fact that the introduced technology has to be shared by so many women that their traditional horticultural technology proves to be more efficient in the long run. Secondly, the fact that many women's user rights are compromised when the necessary information and the authority to decide who, when and how long to use a donor-sponsored appropriate technology are transmitted to men. This is particularly the case when the latter are perceived by the women as being ill-qualified to discern the practicalities involved in using the equipment for which they are responsible.

Projects which fail to transmit the necessary managerial, marketing and technological responsibilities to women, not only fall short of their desired economic viability but also their expectations for attaining entrepreneural success (Kabira \& Nzioki, 1993). Many of them also fail to generate the desired income, primarily because of the disproportionate labour/time/overhead costs. Secondarily because they tend to be duplicated in concentrated areas that share a common market, thus compromising their marketability at the onset. However, the most compelling reason for the apparent 
failure of income-generating projects has to do with the fact that the women involved do not recognise or accept these projects as being their own. They invariably depersonalise donor-imposed projects by tagging them with nicknames such as the "bureau chicken", the "government cow" and the "World Bank water project" (Kabira and Nzioki, 1993). Some of them neglect the donated equipment and opt for their more familial horticultural economy (see also Jackson, 1978). While others invest less time in the imposed projects and devise "self-help harambee and/or alternative income-generating initiatives (Omosa, 1995).

Women criticise the tendency of local and donor bourgeoisie to promote contradictory investment options that shift the burden of development to the rural sector while strategically denying it the necessary structural resources (Nzomo, 1997). This conflict of interests has the impact of legitimising their inertia to deal with the real issues that have contributed to the current economic crisis (see also Haugerud, 1993). Firstly, both fail to acknowledge that poverty and social marginalisation differentially compel both rural and urban women to accept whatever assistance they are offered. Secondly, they fail to recognise some of the endogenous forms of resistance and expressions of autonomy through which women choose to accept or reject the limited options they are presented. Thirdly, they deliberately ignore the fact that the current economic crisis which permeates both the rural and urban sectors, is characterised by comparable asymmetrical diffusions of cultural, demographic, socio-economic, political and even global inter-penetration.

The Women's Bureau : a plethora of competing and conflicting interests

The WB is viewed by the women for whom it is targeted, as promoting the multiple agendas of western feminists, local women elite, local male bourgeoisie and male-dominated foreign donors (referred to in the rest of this article as the "big 4") (Kinuthia, 1993). The "big 4", in the guise of alleviating the constraints of women, are differentially driven to compete against each other and thereby promote the own interests (see also Jaggar, 1993). Accordingly, the y tend to design policies that are conceptually flawed in their favour and to implement projects that are structurally biased against women. The women for whom its benefits are targeted, are obliged to conform to peculiar notions of their production and status in society so as to be legible for funding. Furthermore, the WB is compromised by the underlying feminist undertones that depict local women as being passive, downtrodden and powerless while portraying the "big 4 " as being active, dominant and in control. These gender stereotypes not only tend to be an abstraction of the gender reality at the local scene but also tend to obscure the "big 4's" hidden agenda. The competing interests and power struggles of the "big 4 " are often transposed upon and perpetuated by the WB. Since the WB is designed to promote the "big 4's" agenda, it fails to act in their interest of the women it supposedly represents. WB's failure is also attributed to the fact that it under-funded and attached to a sector of the Ministry of Social an Cultural Services, which addresses marginal issues pertaining to the handicapped, the street children, the homeless and the aged (Nzomo, 1997).

The WB triggers a sense of disillusionment and scepticism amongst Kenyans because of its propensity to grossly misrepresent women's agency in development. Also criticised is its propensity promote feminist interests in development, by capitalising on local women's agency, without necessarily crediting the latter for their achievements. Local feminists have also been accused of attempting to "establish their authority on the 
backs of other women, determining for them the meanings and goals of their lives" (see also Ong, 1988). Today, Kenyans are increasingly opting for the harambee approach, both as a measure of resisting the imposition of both western and local feminists and as means of tempering the anomie inserted by development. They nevertheless maintain their membership to registered organisations so as to gain legitimacy when trying to attract potential independent donors. In integrating the harambee approach to their networking strategy, women not only mobilise themselves into action but also affirm certain development ideals which they find lacking in the "gender-focused" development.

Conclusion

88 The current "gender-focused" development, while supposedly taking into account ail aspects of men and women's relations, tends to obscure the diffusion of roles that have emerged as a consequence of the economic crisis and SAP's-imposed repercussions. It promotes western and local feminists' interests in challenging and countering the monopoly of male bourgeoisie. These feminist strategies have had the impact of inserting a new class of women bourgeoisie who behave in a combatant manner towards their husbands and sons so as to promote this western ideology of autonomy. Conversely, women's autonomy emerges from and is sustained by their capacity to promote their husbands' and sons' interests. Projects which exclude men fail to take into consideration a number of idiosyncratic culture-based and context-specific factors, from which women's autonomy emerges.

89 In Kenya, "gender-focused" development tends to be conceptually flawed due to the tendency of women elite and the government to deprive, limit or distort the relevant facts about the reality of existing on the very fringes of survival. They ignore, either willingly or passively, the very conditions of the women on whose behalf they pretend to act. As a result, the "gender-focused" projects that they promote, tend to be doomed to fail because they do not fit with the contextual reality. Moreover, they tend to promote the Kenyan "politics of bribery and clientelism" whereby one needs to know someone who can connect him or her to the don or funds. However, to get either this "connected" individual or a legitimate share of the donor funds, one is obliged to give something equivalent in return. The people who design projects do not necessarily know their targets or have any control over those who receive the funding or the appropriate technology. Accordingly, those who receive it are relatively free to use it in a manner, other than the one specified in their initial proposal. In the Gusii context, women often look up to their educated and sometimes wealthy or politically influential relatives in order to gain access to donor funds. These relatives, in their turn, can only legitimately gain access to funds in the name of the rural networks they represent. The Gusii do not seem object when these relatives invest some of the donated money in trade or politics since they often claim "it was not ours anyway". However, the y find it offensive when these urban relatives, by virtue of having acquired the funds, presume that the y can dictate to them how to invest it.

90 Men and women's roles tend to alter through contact with other cultures and economic systems. Yet, their views on men and women's relative status remains connected to their underlying cultural valuations of maleness and femaleness. These men and women's partially transformed valuations need to be respected and integrated into "gender-focused" policies in their own terms, no matter how controversial, divergent 
or contradictory they are to politicians, feminists and donors. Men seem to be equally driven and motivated as women to participate in "gender-focused" development.

However, when "gender-focused" policies are based upon certain misconceptions about the position of men, the position of women and the position of men with respect to women, they paradoxically sustain the conditions the y set out to diffuse. This is particularly the case when they inadvertently perpetuate or exacerbate the gender asymmetries that both men and women are confronted and have to cope with in their day-to-day interaction. In some cases, they may even insert unfamiliar gender values that are otherwise absent, thus unnecessarily pitting men and women against each other.

\section{BIBLIOGRAPHY}

Association of African Women in Research and Development (AA WORD), 1995, From Strategies to Action : A Research Perspective, Nairobi, Views Media.

Adhiambo-Oduol J., 1995, "Research Priorities in WID Issues in Kenya", in AA WORD. (eds), From Strategies to Action : A Research Perspective, Nairobi : Views Media. Amnesty International, 1995, "Women in Kenya : Repression and Resistance", London.

Bulow D., 1992, "Bigger Than Men ? Gender Relations and Their Changing Meaning in Kipsigis Society", Kenya, Africa 62(4).

Callaway B., 1984, "Ambiguous Consequences of the Socialisation and Seclusion of Hausa Women", Journal of Modem African Studies, 22(3) : 429-450.

Daily Nation, 2001, "Conference for East African Women Parliamentarians", 8th March, Nairobi.

Dolphyne F.A., 1991, The Emancipation of Women : An African Perspective, Accra, Ghana University Press.

Francis E., 1995, "Migration and The Changing Divisions of Labour : Gender Relations and Economic Change in Koguta, Western Kenya", Africa 65(2) : 196-215.

Glazer I.M., 1991, "Serving up WID : Is the Cup Half Empty or Half Full ?", Reviews in Anthropology, vol. $16: 11-15$.

Gluckman M., 1950, "Kinship and Marriage Among the Lozi of Northern Rhodesia and the Zulu of Natal", in Radcliffe-Brown A. R. et al (eds) African Systems of Kinship and Marriage, London, Oxford University Press.

Hakansson T., 1994, "The Detachability of Women : Gender and Kinship in Processes of Socio-economic Change among the Gusii of Kenya", American Ethnologist, 21(3) : 516-538.

Hakansson T., 1988, Bridewealth, Women and Land: Social Change among the Gusii of Kenya, Uppsala Studies in Cultural Anthropology, 10, Stockholm, Almqvist and Wiksell International.

Hakansson T., 1989, "Family Structure, Bridewealth and Environment in Eastern Africa : A Comparative Study of House Property Systems", Ethnology, 28 : 117-34. 
Hartman H., 1979, "The Unhappy Marriage of Marxism and Feminism : Towards a More Progressive Union", in Sigot, A. et al (eds), Towards Common Ground : Gender and Natural Resource Management in Africa, African Centre for Technological Studies (ACTS), Centre for International Development and Environment (CIDE) and World Resources Institute (WRI) Environmental Policy Series $n^{\circ} .6$, Nairobi, English Press.

Haugerud A., 1993, The Culture of Politics in Modern Kenya, Cambridge, Cambridge University Press.

Henn J.K., 1988, "The Material Basis of Sexism : A Model of Production Analysis", in Stichter S. B. et al (eds), Patriarchy and Class : African Women in the home and the Workforce, London, Westview Press.

Jackson C., 1978, "Hausa Women on Strike", in Stamp, P. (ed.), Technology, Gender and Power in Africa, Ottawa, Ont., International Development Research Centre Technical study 63e (IDRC-TS63e).

Jaggar A., 1983, "Feminist Politics and Human Nature", in Stamp, P. (ed.), Technology, Gender and Power in Africa, Ottawa, Ont., IDRC-TS63e.

Kabira W.M., Nzioki E.A., 1993, Celebrating Women's Resistance : A case Study of Women's Groups Movement in Kenya. Nairobi, New Earth Publications.

Kameri-Mbote P., 1995, "The Legal Status of Women in Kenya", in AA WORD. (eds), From strategies to action : a research perspective, Nairobi, Views Media.

Kameri-Mbote P. \& W. Kiai 1993. "The Women's Movement in Kenya : An Overview", in Khasiani S.A. et al (eds.), The Women's Movement in Kenya, Nairobi, High-Tech Computer Applics Agencies.

Khasiani S.A., Njiro E.I., 1993, The Women's Movement in Kenya. Nairobi, High-Tech Computer Applics Agencies.

Khasiani S.A., 1993, "The Impact of the Women's Movement on Institutions in Kenya", in Khasiani S.A. et al (eds.), The Women's Movement in Kenya, Nairobi, High Tech Computer Applics Agencies.

Kinuthia C., 1993, "Women Groups in Kenya with Special Reference to Housing and Community Development", in Khasiani S. A. et al (eds.), The Women's Movement in Kenya, Nairobi, High-Tech Computer Applics Agencies.

Korten D.C., 1993, "People Centred Development", in Dialogue Journal "Development or chaos", New Series-N.1-November/December, Varese, Milano Ferrovia Corrispondenza.

Lambert H.E., 1965, "Kikuyu Social and Political Institutions", in S. A. Khasiani et al (eds), The Women's Movement in Kenya, Nairobi, High-Tech Computer Applics Agencies.

Macharia K., 1997, The Social and Political Dynamics of the Informal Economy in African Cities, Lanham, Maryland, University Press of America.

Moser C.O.N., 1989, "Gender Planning in the Third World : Meeting Strategic and Practical Gender Needs". World Development 17 (11) : 799-825.

Mugo M., 1975, "The Role of Women in the Struggle for Freedom", in Pala, A. et al (eds,) The Participation of Women in Kenyan Society, Nairobi, Kenyan Literature Bureau.

Nyanchama-Okemwa S., 1996, "De Vrouw in de Civiele Maatschappij : Factoren die de Civiele Status van Vrouwen in Kenya Beinvloeden", in Noord-Zuid Cahier "Africa Grijpt Zijn Kans", Belgium, Wereldwijd. 
Nzomo M., 1997, "Kenyan Women in Politics and Public Decision-making", in Mikeli G. (ed), African Feminism : The Politics of Sun1ival in Sub-Saharan Africa, Philadelphia, University of Pennsylvania Press.

Nzomo M., 1993, "The Kenyan Women's Movement in a Changing Political Context", in Khasiani S. A. et al, The Women's Movement in Kenya, Nairobi, High-Tech Computer Applics Agencies.

Oboler R.S., 1994, "The House Property Complex and African Social Organisation", Africa 64 (3).

Oduol W.A., 1993, "Kenyan Women's Movement and Women's Political Participation". In : Khasiani S.A. et al (eds), The Women's Movement in Kenya Nairobi, High-Tech Computer Applics Agencies.

Omosa M., 1995, "Persistent Cultural Practices : A Review of the Status of Women in Kenya", in AA WORD (eds), From Strategies to Action : A Research Perspective, Nairobi, Views Media.

O'Neal M., 1986, Forward-looking Strategies : The UN World Conference on Women, Ottawa, Ont., Canadian Woman Studies/Les Cahiers de la femme, 7(112) : 19-21.

Ong A., 1988, "Colonialism and Modernity : Feminist Representations of Women in Non-western Societies", in Schuurman F. J. et al (eds), Beyond the Impasse, New Directions in Development Theory, London, Zed Books.

Parkin D., 1972, Palms, Wine and Witnesses : Public Spirit and Private Gain in an African Farming Community, San Francisco, Chandler Publishing Co.

Schuurrnan F.J., 1993, Beyond the Impasse : New Directions in Development Theory, London, Zed Books.

Sigot A., Thrupp L.A., Green J., 1995, Towards Common Ground : Gender and Natural Resource Management in Africa, ACTS, CIDE and WRI Environmental Policy Series $n^{\circ} 6$, Nairobi, English Press.

Sigot A., 1995, "Discourse on Gender and Resource Management", in Sigot et al (eds), Towards Common Ground: Gender and Natural Resource Management in Africa, ACTS, CIDE and WRI Environmental Policy Series $n^{\circ}$ 6, Nairobi, English Press.

Snyder M.C., Tadesse M., 1995, African Women and Development, Johannesburg, South Africa, Witwatersrand University Press.

Stichter S.B., Parpart J.L., 1988, Patriarchy and Class : African Women in the Home and the Workforce, London, Westview Press.

Stamp P., 1989, Technology, Gender and Power in Africa, Ottawa, Ont., IDRC-TS63e.

Temmerman E., 1995, Kenyaanse Vrouwen Lijden Onder Wilde Polygamie, Belgie, De Standaard.

Ventura-Dias V., 1985, "Modernisation, Production Organisation and Rural Women in Kenya", in Stamp, P. (ed) Technology, Gender and Power in Africa, Ottawa, Ont., IDRC-TS63e.

White L., 1988, "Domestic Labour in a Colonial City : Prostitution in Nairobi, 1900-1952", in Stichter S. B. et al (eds), Patriarchy and Clois : African Women in the Home and the Workforce, London, Westview Press.

Wipper A., 1982, "Women's Voluntary Associations", in Hay, M. J. et al (eds), African Women South of the Sahara, Harlow, Longman.

Woestman L., 1994, "World Bank Structural Adjustment and Gender Policies : Strangers Passing in the Night, Fleeting Acquaintances or Best Friends, The Hague, EURODAD and WIDE position paper. 
AUTHOR

STELLA NYANCHAM-OKEMWA

Department of Social and Cultural Anthropology, Katholiek Universiteit Leuven, Belgique. 